\title{
Status of clover root weevil and its biocontrol agent in the South Island after six years.
}

\author{
C.M. FERGUSON ${ }^{1}$, M.R. MCNEILL ${ }^{2}$, C.B. PHILLIPS ${ }^{2}$, S. HARDWICK ${ }^{2}$, D.M. BARTON ${ }^{1}$ and J.M. KEAN ${ }^{3}$. \\ ${ }^{1}$ AgResearch, Invermay Agricultural Centre, Private Bag 50034, Mosgiel \\ ${ }^{2}$ AgResearch, Lincoln Research Centre, Private Bag 4749, Christchurch \\ ${ }^{3}$ AgResearch, Ruakura Research Centre, Private Bag 3123, Hamilton \\ colin.ferguson@agresearch.co.nz
}

\begin{abstract}
Clover root weevil was first discovered in the South Island in 2006. Since then its distribution has been monitored. Although not yet occurring throughout all the South Island, it is widespread and has become common in many regions. The first releases of a biocontrol agent, the Irish ecotype of the parasitoid wasp Microctonus aethiopoides, were also made in 2006 , with more made as suitable weevil populations were detected. In all areas where the releases have been monitored the biocontrol agent has established and extensive natural spread has occurred from the earlier release sites. As a consequence it is now established extensively in the northern South Island. Targeted releases have established the agent in Canterbury, Otago and Southland.
\end{abstract}

Keywords: Biocontrol, clover root weevil, Sitona lepidus, Microctonus aethiopoides

\section{Introduction}

The 1996 discovery of clover root weevil (CRW) in New Zealand (Barratt et al. 2006), its subsequent spread through the North Island (Gerard et al. 2011), the impact on white clover in pastures (Eerens et al. 2005; Gerard et al.2007) and its potential economic cost (Wear \& Andrews 2005) are well documented. It has been the most significant invasive pasture pest to establish in New Zealand since black beetle in the 1930s, and the only one capable of achieving nationwide major pest status since the arrival of Argentine stem weevil early last century (Marshall 1937). Given its wide Northern Hemisphere distribution, it was expected to eventually colonise all of New Zealand (Willoughby \& Addison 1997). By 2006 it had spread throughout the North Island, several specimens had been detected near Christchurch airport, and established populations had been discovered near Nelson at Richmond and Rai Valley (Phillips et al. 2007). It continued spreading in the South Island, being found in Otago in 2009 and Southland in 2010 (Phillips et al. 2010).

Control of CRW is problematic. Adult weevils can be killed with organophosphate insecticides, although only chlorpyrifos is registered for this use. Adult weevils often fly during spring and summer, so rapid re-invasion of treated pastures from surrounding untreated areas can occur. The particularly damaging soil-dwelling larval stages are much more difficult to treat, with no insecticides being registered for this use. Soon after CRW had been detected in New Zealand, AgResearch entomologists responded to pastoral industry concerns by advocating biocontrol (Goldson et al. 2001) as a long term solution that could be implemented without requiring significant changes to farm systems (Gerard et al. 2007). A search for suitable biocontrol agents was initiated in 1997, which culminated in the 2006 introduction and release of an Irish ecotype of Microctonus aethiopoides Loan (Hymenoptera: Braconidae), a small parthenogenetic parasitic wasp (Gerard et al. 2007, 2011) each of which can potentially parasitise up to 60 weevils. The wasp was released widely throughout the North Island into weevil populations that had often been present for several years, having spread at 10-70 km/year since 1996 (Hardwick et al. 2004). The releases were successful, with the wasp establishing promptly, and thereafter spreading at $c a .15 \mathrm{~km} /$ year. As a result it was probably distributed throughout the North Island by summer 2010/11 (Gerard et al. 2010; P. Gerard, pers. comm. 2012). CRW was in the early stages of colonising the South Island when the biocontrol agent first became available for release. This provided an opportunity for the wasp to be quickly released into localised weevil populations so it would subsequently disperse and establish into new areas with the weevil. Between August 2006 and March 2007, the wasp was released in Richmond and the Rai Valley, and in 2008 parasitised weevils were found near Blenheim indicating the strategy had been successful (Phillips et al. 2007, 2010). On the east of the South Island CRW populations expanded up to $19 \mathrm{~km} / \mathrm{yr}$, probably through adult flights, while discrete new CRW populations were found up to $250 \mathrm{~km}$ apart, suggesting that accidental human-assisted dispersal had also played a significant role in the pest's spread (Phillips et al. 2010). These disparate new populations established without the wasp and, if natural spread was solely relied on, it could have 
taken a decade or more for the wasp to arrive at the most distant weevil infestations (Phillips et al. 2010). To accelerate biocontrol, further wasp releases were required. These were also aimed to establish biological control as early as possible within weevil populations and enable spread of the wasp with the weevil as dispersal occurred from these loci. This paper reports on the ongoing effort to mitigate the impact of CRW in the South Island and describes the success of some early releases of the biocontrol agent.

\section{Methods}

\section{CRW and biocontrol agent detection.}

Phillips et al. (2010) described the methods used to assess the spread of CRW in the South Island. In brief, the South Island was divided into $20 \times 20 \mathrm{~km}$ squares, each representing a sampling area which was prioritised for sampling based both on land use and on results from any previous samples. Advantage was taken of sampling from other investigations, serendipitous observations were incorporated, and any public reports of sightings were followed up for confirmation. As CRW became more common in the South Island, the frequency of reports of pasture damage received from farmers, consultants and associated industry personnel increased, and those verified increasingly contributed to the data collected. Locations of wasp releases were revisited to confirm establishment and, in selected cases, to monitor build up and spread of the wasp. CRW presence was determined by sighting weevils, or using a modified blowervac to make collections. The presence of the wasp was usually confirmed by maintaining $c a$. $100 \mathrm{CRW}$ in cages to allow in natura development of the wasp larvae to adult and/or dissecting 50-100 weevils. Rearing the wasps enabled both accurate identification of the wasp species and overall number of wasps that successfully developed per 100 weevils. Dissections determined the proportion of weevils parasitised. As multiple wasp larvae may parasitise a single weevil, the two methods measure different aspects of the wasp's effect on weevil populations, but both provide an indication of wasp establishment and increase. The information collected was used to update a central database and reprioritise areas to be sampled.

\section{Biocontrol agent release}

Selection of wasp release sites was primarily influenced by the presence of CRW at densities deemed sufficient to support establishment. No precise threshold was set, but obvious damage to clover and the presence of many CRW in blowervac samples were used as key indicators. To optimise the benefits of biocontrol over a wide area, releases were made least $40 \mathrm{~km}$ apart to capitalise on the wasp's natural $17 \mathrm{~km} /$ year spread rate. As CRW damage

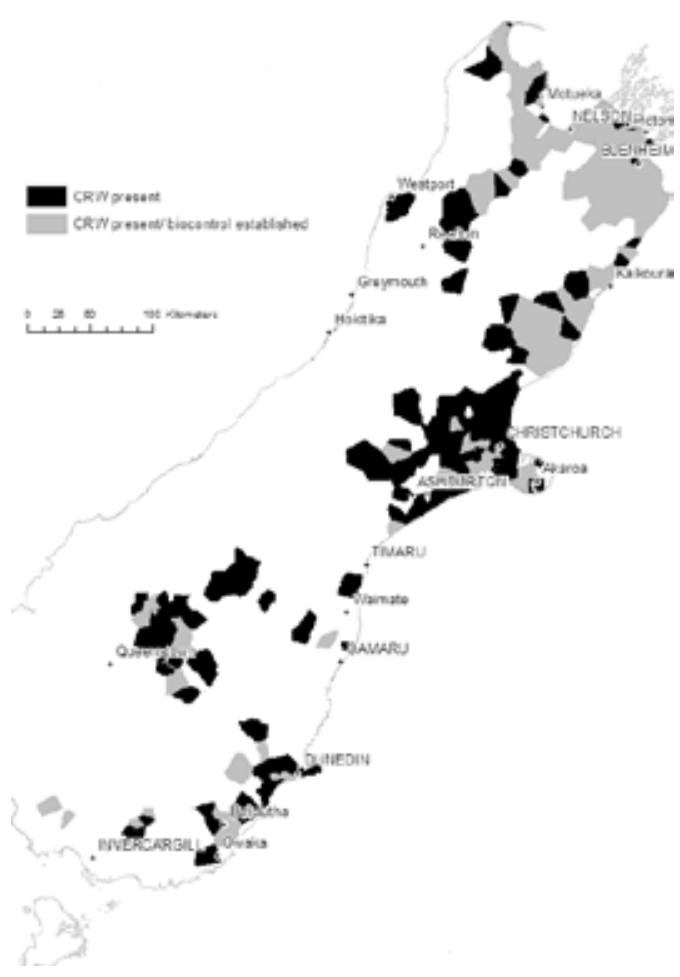

Figure 1. Known distribution of clover root weevil and its biocontrol agent, M. aethiopoides, in the South Island June 2012.

increased, farmers often requested wasp releases in their areas, and these requests were accommodated where possible and potentially beneficial. Wasps were released as larvae within parasitised weevils using $c a$. 500-2000 weevils per release, with known rates of parasitism. Sites at Rotherham (releases in 2009, 2010) and Lincoln (a naturally established population), in Canterbury, and at Invermay Agricultural Centre, near Mosgiel (release in 2010), in Otago were monitored monthly to measure the establishment and increase of the wasp. Others at Rakaia Island, Burnt Hill, Methven, Lowcliffe, a second Taieri site, Matura and Woodlaw were monitored less frequently. Releases made in Otago (East Otago Plateau (2), Central Otago (3), South Otago (6)) and Southland (Gore (1), Drummond (1)) in 2011/12 have yet to be assessed.

\section{Results}

\section{Clover root weevil}

Since monitoring the South Island began in 2006, CRW has been found at 464 of 799 sites inspected to June 2012. The current known distribution is shown 


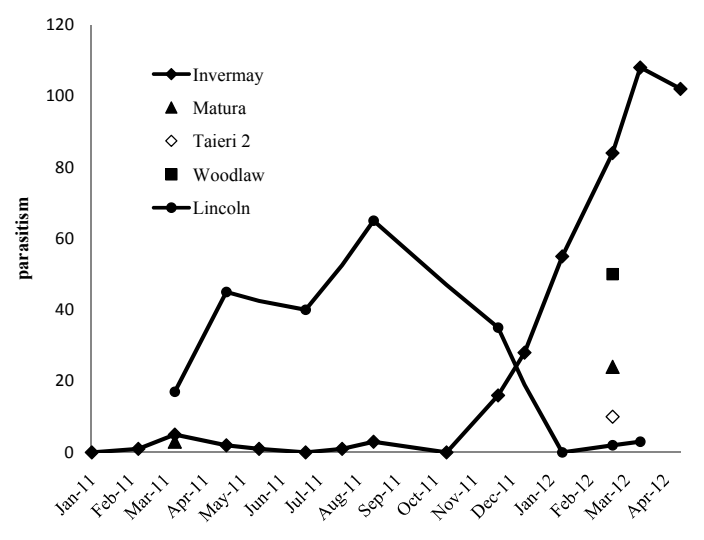

Figure 1. Parasitism (\% parasitism at Lincoln, Number of wasps/100 weevils for Otago and Southland) of clover root weevil by the wasp, M. aethiopoides, after releases in Otago and Southland.

in Figure 1. Populations that were discrete in winter 2010 (Phillips et al. 2010) have largely coalesced, particularly in Canterbury, Marlborough and Nelson; in addition, the weevil has increased in abundance and invaded new pastures and localities. Nearly all low lying pasture areas in the northern part of the South Island and central Canterbury are now infested, and the weevil has recently been found in Buller on the West Coast. Two years ago, CRW appeared to be absent from South Canterbury and North Otago. That has changed with the weevil apparently spreading south from Ashburton and populations establishing at Waimate, extensively in Waitaki Valley and Mackenzie Basin. On Taieri Plain, populations that were first found in summer 2009/10 have become extensive, covering the entire plain, and are contiguous with South Otago populations that were small and patchy in 2010 , but which are now readily observed. The weevil has moved inland from the Otago coast, is common on the East Otago Plateau and has become abundant in central Otago. Reports of the weevil, or its effects, coming from farmers in all these regions have become much more frequent. In Southland, CRW has had a lower profile, but weevils were discovered at Drummond in March 2012, and in the Catlins area in 2011 suggesting that the weevil is also increasing its presence in the far south, although less noticeably than elsewhere.

\section{Biocontrol agent releases}

Biocontrol agent releases have been made at 27 South Island locations, and the wasp has been recovered from 111 sites. Most recoveries $(n=92)$ were from weevil populations in Nelson, Marlborough and North Canterbury. Releases were made at five sites at the top of the South Island, two near Richmond (2007 and 2010), two in the Rai Valley (2007) and one at Upper Takaka (2009). The next nearest sites to Richmond and Rai Valley were at Rotherham in North Canterbury, $150 \mathrm{~km}$ south, in 2009 and 2010. The recoveries made north of Christchurch indicate that the biocontrol agent is spreading with its host. In Central Canterbury, recoveries have been made from 20 pastures and most of these appear to be associated with the initial arrival of the wasp at Lincoln through natural spread. The wasp has established at four of the intentional Canterbury release sites and at Georgetown in South Canterbury, but dispersal from these has so far been limited. In the southern South Island, 17 releases have been made, but only four of these sites have so far been assessed for establishment, which has occurred in each case.

\section{Monitored biological control agent release sites}

The arrival of the wasp at Lincoln in Canterbury, presumably through natural spread, was first noticed in March 2011. Seventeen percent of weevils were initially parasitised, but this increased over the winter to a maximum of $70 \%$ before declining as a new adult generation of weevils emerged from the soil in spring and summer diluting the level of parasitism (Fig 2). The first release made in Otago was at Invermay Agricultural Centre in December 2010 in which an estimated 117 wasps emerged from 1000 parasitised weevils, and establishment was confirmed after 2 months. However, the proportion of CRW parasitised remained below 5\% until December 2011. In summer 2011/12, this increased rapidly and 108 wasps were reared from a reared sample of 100 weevils (Figure 2) which would have been approximately equivalent to $70 \%$ of weevils being parasitised (P. Gerard pers. comm.). The second release made on the Taieri Plain (Taieri 2) was $8.5 \mathrm{~km}$ SW of Invermay in February 2011 using 1200 weevils from which 137 wasps emerged. Again establishment was successful, although levels remained undetectable until February 2012 when 10\% of weevils were found to be parasitised (Fig 2). In Southland, 2500 parasitised weevils were released into a dairy pasture at Matura in December 2010. The wasp was detected 2 months later, but by February 2012 only $24 \%$ of weevils were parasitised (Fig 2). Greater success was achieved at Woodlaw where 221 wasps successfully emerged from 1200 caged weevils after release in March 2011. Although no recoveries were made until February 2012 , at that time $50 \%$ of the weevils collected were parasitised (Fig 2).

The low numbers of wasps emerging from weevil releases at Invermay, Taieri 2 and Woodlaw are associated with the release method used, which will be reported on elsewhere (S. Hardwick in prep). 


\section{Discussion}

The invasion of New Zealand pastures by CRW is unrelenting, and the prediction that CRW would eventually colonise nearly all of New Zealand is being realised. The CRW populations initially detected in the South Island were localised and discrete, and probably arose from human assisted introductions. With time, these populations have become increasingly merged due to natural CRW dispersal and accidental human assisted movements. Both mechanisms are probably associated with the appearance of populations in Central Otago, Mackenzie Basin, South Canterbury, Waitaki Valley and Buller. Although some areas appear to be free of CRW, it is possible that populations are present but have not yet been detected. In Southland, the chance discovery of a low population at Drummond in autumn 2012, and a small Catlins population in winter 2011, suggest that similar low level infestations may occur elsewhere in the region. The intensively farmed Southland plains may soon face increasing weevil pressure, and these are areas that warrant closer future scrutiny. South Canterbury, while largely appearing free of CRW, has populations to the northeast and south-west, and the population found near Waimate again suggests increased presence is likely soon. The West Coast of the South Island, although not yet thoroughly sampled, may similarly be about to face invasion by CRW, as confirmed by findings in Buller and close to Haast Pass at Hawea Flat.

Where released, the wasp has generally established and rapidly increased in numbers, although build up may have happened more quickly in the warmer northern regions than in Otago and Southland. Parasitism rates measured at Invermay in autumn 2012 suggest that, even if build up is slower in the south, this does not prevent the wasp achieving very high levels of parasitism and exerting considerable pressure on weevil populations. The initially low incidence of the wasp at Invermay following its release indicates that it could have been present at Lincoln for some time before it was detected. However, the patterns of parasitism over time at the two sites (Fig 2) are very different, and wasp phenologies may vary with location, indicating a need for further investigation. It is interesting that the parasitism levels observed in New Zealand far exceed those observed in the wasp's native Ireland where 7\% was the maximum recorded by McNeill et al. (2006) during the original search for a CRW biocontrol agent. This may reflect that the same factors associated with CRW becoming a pest in New Zealand; abundant food resource, lack of competition and few natural enemies, may also be associated with the wasp being a much more effective natural regulatory agent than in its home range (S. Goldson pers. comm.). Natural spread of the wasp in the northern South Island has been tracking CRW spread, and confirms the success of the initial introduction strategy for the wasp in Richmond and the Rai Valley. This also appears to be the case in Canterbury, although monitoring around the Methven and Lowcliffe release sites is required to confirm this. Despite this, it will be beneficial to introduce the wasp to other weevil populations to hasten more complete coverage of the South Island. There is increasing pressure on Otago farms from CRW because previously low or undetected populations grew rapidly in summer 2011/12, thereby "getting a jump" on the wasp. Farmer concerns about the impacts these were having on their pastures led directly to more releases of the wasp, and this is likely to continue in 2012/13. The same is happening in Mid and South Canterbury, although it is possible that more rapid dispersal of the wasp similar to that seen in Canterbury may mitigate the number of releases required there. In Southland, enquiries from farmers and associated industries have been fewer, but are almost certain to rise as time progresses.

As yet, CRW is not fully occupying its potential range, but at the observed rate of spread this will occur in the near future. Neither is the wasp completely coexistent with the weevil, with some CRW populations free from the biocontrol agent. While eventually natural dispersal of the wasp will probably achieve this, further releases of the wasp will accelerate the process and reduce the impact the weevil will otherwise have on South Island farms.

\section{ACKNOWLEDGEMENTS}

The authors would like to thank all farmers who have allowed access to their properties, particularly those hosting releases of the biocontrol agent. The CRW biocontrol programme has had long term support from New Zealand farmers via DairyNZ and Beef + Lamb New Zealand and from the FRST/MSI Ecosystems Bioprotection programme. Environment Southland support has complemented these sources in Southland.

\section{REFERENCES}

Barratt, B.I.P.; Barker, G.M.; Addison, P. J, 1997. Sitona Lepidus Gyllenhal (Coleoptera: Curculionidae) a potential clover pest new to New Zealand. New Zealand Entomologist 19: 23-30

Barratt, B.I.P.; Evans, A.A.; Ferguson, C.M. 1997. Potential for control of Sitona lepidus Gyllenhal by Microctonus spp.. New Zealand Plant Protection 50: 37-40

Eerens, J.P.J.; Hardwick, S.; Gerard, P.J.: Willoughby, B.E. 2005. Clover root weevil (Sitona lepidus) in New Zealand: the story so far. Proceedings of the New Zealand Grassland Association 67: 19-22. 
Gerard, P.J.; Hackell, D.L.; Bell, N.L. 2007. Impact of clover root weevil Sitona lepidus (Coleoptera: Curculionidae) larvae on herbage yield and species composition in a ryegrass-white clover sward. New Zealand Journal of Agricultural Research 50: 381392

Gerard, P.J.; Wilson, D.J.; Eden, T.M. 2010. Clover root weevil biocontrol distribution in the North Island release tactics and outcomes. Proceedings of the New Zealand Grassland Association 72: 85-89.

Gerard, P.J.; Wilson, D.J.; Eden, T.M. 2011. Field release, establishment and initial dispersal of Irish Microctonus aethiopoides in Sitona lepidus populations in northern New Zealand pastures. BioControl 56: 861-870

Goldson, S.L.; Phillips, C.B.; McNeill, M.R.; Proffitt, J.R.; Cane, R.P. 2001. Importation to New Zealand quarantine of a candidate biological control agent of clover root weevil. New Zealand Plant Protection 54: 147-151.

Marshall, G.A.K. 1937. New Curculionidae collected from New Zealand. Transactions of the New Zealand Institute 67: 316-340
McNeill, M.R.; Proffitt, J.R.; Gerard P.J.; Goldson S.L. 2006 Collections of Microctonus aethiopoides Loan (Hymenoptera: Braconidae) from Ireland. New Zealand Plant Protection 59: 290-296.

Phillips, C.B.; McNeill M.R.; Hardwick, S.; Vink, C.J.; Kean, J.M.; Bewsell, D.; Ferguson, C.M.; Winder, L.M.; Iline, I.I.; Barron, M.C.; Stuart, B. 2007. Clover root weevil in the South Island: detection, response and current distribution. New Zealand Plant Protection 60: 209-216

Phillips, C.B; McNeill, M.R.; Hardwick, S.; Ferguson, C.; Kean, J.M. 2010. South Island distributions of clover root weevil and its biocontrol agent. Proceedings of the New Zealand Grassland Association 72: 227-232.

Wear, S.; Andrews, G. 2005. Clover root weevil economic impact assessment: Report to Biosecurity New Zealand, Ministry of Agriculture and Forestry. Wellington, NZIER. 35pp.

Willoughby. B.; Addison, P. 1997. Clover root weevil (Sitona lepidus) - a threat to the sustainability of white clover in New Zealand pastures? Proceedings of the New Zealand Grassland Association 59: 23-27. 
